\title{
Total and Methylmercury in Soft Tissues of White-Tailed Eagle (Haliaeetus albicilla) and Osprey (Pandion haliaetus) Collected in Poland
}

\author{
Elzbieta Kalisinska, Jerzy Gorecki, Natalia Lanocha, Anna Okonska, \\ Javier B. Melgarejo, Halina Budis, Izabella Rzad, Jerzy Golas
}

Received: 27 August 2013/Revised: 26 March 2014/ Accepted: 2 May 2014/Published online: 29 May 2014

\begin{abstract}
Mercury ( $\mathrm{Hg})$ contamination in piscivorous birds, especially methylmercury ( $\mathrm{MeHg}$ ), has been drawing much attention worldwide in regard to its bioaccumulation and biomagnification in food chains. In this study on $\mathrm{Hg}$ in the soft tissues of white-tailed eagles $(n=22)$ and ospreys $(n=2)$ from Poland, total $\mathrm{Hg}(\mathrm{THg})$ range was $0.15-47.6$ while $\mathrm{MeHg}$ range was $0.11-8.05 \mathrm{mg} \mathrm{kg}^{-1}$ dry weight. In both species, median $\mathrm{THg}$ and $\mathrm{MeHg}$ concentrations were lower in the muscle and brain than in the liver and kidney. Median nephric residues were just under 3 and $5 \mathrm{mgTHg} \mathrm{kg}^{-1}$ or 0.9 and $3.7 \mathrm{mgMeHg} \mathrm{kg}^{-1}$ for whitetailed eagle and osprey, respectively. In Norwegian data from the 1970s and in our results, $\mathrm{MeHg}$ in the muscle of white-tailed eagle was $\sim 60 \% \mathrm{THg}(\% \mathrm{MeHg}=\mathrm{MeHg} /$ $\mathrm{THg} \times 100$ ), lower than in other piscivorous birds. A clear similarity in $\mathrm{THg}$ tissue levels was found between Polish and German populations of white-tailed eagles.
\end{abstract}

Keywords Falconiformes · Piscivorous birds · Organic and inorganic mercury · Accumulation ·

Tissue differences

\section{INTRODUCTION}

According to the European Union Bird Directive (2009/147/ EC), the white-tailed eagle Haliaeetus albicilla and osprey Pandion haliaetus are rare protected species of Falconiformes. In Europe, breeding populations of white-tailed eagle and osprey are estimated at 5000-6600 and 7600-11 000 pairs, respectively. The white-tailed eagle has its strongholds in Norway and Russia, with significant populations in Sweden, Poland and Germany, with key breeding areas of the osprey in Sweden, Russia and Finland (BirdLife International 2004). In Europe, the migratory status of the white- tailed eagle is 'resident' or 'mainly resident' yet the osprey is full migrant. Both species are long lived and in the wild can live up to 25 years. The eagle matures sexually at 5 years and osprey at 3 years. Both are top predators and their diet is mainly fish, although the white-tailed eagle feeds on waterfowl and animal carcasses (Forsman 1999).

As piscivorous species, the white-tailed eagle and osprey are exposed to chronic or acute poisoning with mercury $(\mathrm{Hg})$, especially methylmercury (MeHg), in their food (Holt et al. 1979). Research from the 1950s and later showed that among the various $\mathrm{Hg}$ species present in nature, $\mathrm{MeHg}$ is the main cause of neurological, neuromotorical, behavioural and reproductive disorders in warm-blooded vertebrates (Clarkson and Magos 2006; Rutkiewicz et al. 2011). The most considerable $\mathrm{Hg}$ poisonings of birds of prey were recorded between 1960 and 1980 when agriculture in developed countries based on the use of pesticides (especially, fungicides containing $\mathrm{MeHg}$ ) for grain seed dressing. The treated grain was consumed by small birds and mammals, which in turn were a source of food for terrestrial predators. Also the fungicides washed from fields reached water bodies and contaminated aquatic food webs, leading to a catastrophic decrease of local populations of fish-eating birds (white-tailed eagle, bald eagle Haliaeetus leucocephalus and osprey) in Europe and North America. Moreover, $\mathrm{MeHg}$ undergoes biomagnification, especially in aquatic ecosystems (Scheuhammer et al. 2007). Despite the abandonment of $\mathrm{Hg}$-pesticides in Europe and North America in 1980-1990s and many attempts to decrease anthropogenic $\mathrm{Hg}$ emissions, its various forms are still present in the environment worldwide (Larson 2014).

Birds are mainly exposed to $\mathrm{Hg}$ coming from the alimentary tract. Their food contains inorganic $\mathrm{Hg}$ ( $\mathrm{InHg}$ ) and organic forms, among which $\mathrm{MeHg}$ is the most prevalent. The absorption of $\mathrm{MeHg}$ and $\mathrm{InHg}$ from the avian digestive 
tract may be 99 and $20 \%$, respectively (Gochfeld 2003; Clarkson and Magos 2006). The greatest amounts of $\mathrm{MeHg}$ can be found bound in the plumage $(70-90 \%$ of total $\mathrm{Hg}$, THg, accumulated in the avian body). Importantly, this $\mathrm{MeHg}$ is only transported to growing feathers to be shed during moulting. Half of the remaining THg is accumulated in muscles and the other half in other tissues, especially in the liver and kidneys (DesGranges et al. 1998). At the same time, they are the most efficient at $\mathrm{MeHg}$ demethylation, which results in the production of $\mathrm{InHg}$ and dynamically changing proportions of $\mathrm{MeHg}$ and InHg. This process occurs in the brain too. Muscles, feathers and eggs show little or no evidence of the demethylation (Scheuhammer et al. 2008). There are less data on the accumulation of $\mathrm{THg}$ and $\mathrm{MeHg}$ in the muscle and brain in piscivorous birds than the liver and kidneys (Shore et al. 2011). Muscles, unlike the liver and kidneys, are the main consumable part of the bird body and largely contribute to the transfer of $\mathrm{MeHg}$ to predators and scavengers. It is, therefore, justified to study not only hepatic and nephric $\mathrm{THg}$ and $\mathrm{MeHg}$ concentrations, but also their remains in avian muscle and brain (as a target organ of $\mathrm{MeHg}$ ).

In formulating our hypothesis and the aim of ecotoxicological research, we took into account: special interest of European Union (EU) in the protection and monitoring of rare species; dynamic changes in the environment in Europe induced by socio-economic transformations; and potential exposure piscivorous birds to $\mathrm{Hg}$. Our hypothesis assumed that the abandonment of Hg-pesticides has contributed to a decreased exposure of fish-eating Falconiformes. The verification of the hypothesis was conducted in the investigation of $\mathrm{THg}$ and $\mathrm{MeHg}$ residues in soft tissues of two rare piscivorous species: the white-tailed eagle and the osprey, collected in Poland after 1995, and comparison of the data with the analogous data published so far. In Europe, the current study is the second to investigate both $\mathrm{THg}$ and $\mathrm{MeHg}$ levels in soft tissues of the aforementioned species, the first one was published in Norway in 1970s. Reports on THg in birds are more frequent and can be used for interregional comparisons.

\section{MATERIALS AND METHODS}

\section{Study Area}

The current population of the white-tailed eagle in Poland is estimated at 670 breeding pairs. At the end of the 1990s, the greatest numbers of pairs were observed in northwestern Poland (Voivodeship Zachodniopomorskie, VZach: $n=180$ ) and north-eastern Poland (Voivodeship
Warminsko-Mazurskie, VWar-Maz: $n=150$ ) (Cenian et al. 2006). In central Poland, few nests are found mainly due to its more industrial and agricultural character, fewer water bodies and forested areas. In the Voivodeship Lodzkie (VLodz), the number of breeding pairs is $\sim 15$ (Anderwald et al. 2007). Many white-tailed eagles breeding in Poland winter in their own nests or move further west. The greatest wintering populations can be found in NW Poland, sometimes up to 200 individuals have been observed around the Szczecin Lagoon (Hauff and Mizera 2006).

Currently, about 25-30 pairs of osprey breed in Poland, mainly in northern and western part of the country (Mizera 2009). Throughout the country numerous ospreys migrate that breed in North Europe (Forsman 1999).

The Polish energy sector is based on coal combustion, which results in high $\mathrm{Hg}$ emission. However, a distinct $60 \%$ decline in $\mathrm{Hg}$ emissions has been observed in Poland since the 1990s, down to 13.5 tonnes in 2010 (Panasiuk and Glodek 2013). In VZach, VWar-Maz and VLodz, Hg emissions in 2007 were, respectively, 0.51, 0.14 and 1.97 tonnes (Debski et al. 2009). A decrease in Hg concentrations was observed in fish from the Southern Baltic, potential food for osprey and white-tailed eagle. The fish examined between 1990 and 2010 had average concentrations $<0.50 \mathrm{mgHg} \mathrm{kg}^{-1}$ wet weight (Polak-Juszczak 2013).

\section{Sampling}

Between 1996 and 2012 twenty-two dead specimens of the white-tailed eagle were collected in three regions of Poland: VZach, VWar-Maz and VLodz. Two dead ospreys were found in VZach (Table 1; Fig. 1). The collection of carcasses of the species was performed in compliance with Polish law. Until analysis, the carcasses were stored at $-20{ }^{\circ} \mathrm{C}$. After defrosting, the specimens were classified to an age group (based on the morphological characteristics of the plumage and beak), and sex of birds was established by inspection of the gonads during autopsy (Forsman 1999). The 22 white-tailed eagles were divided into three age groups (immature, between 5 months and 4 years; subadult, 4th year; adult, 5 years and older) and the two ospreys into two age categories (immature and adult). Samples of liver, kidney and breast muscle were taken from all individuals. In 8 of the eagles, it was impossible to collect whole brains so only THg was determined (Table 1).

\section{Mercury Analysis}

The assays involved determinations of tissue per cent water content (by weight) and concentrations of $\mathrm{THg}$ and $\mathrm{MeHg}$. 
Table 1 Origin of soft tissues of the white-tailed eagle Haliaeetus albicilla and osprey Pandion haliaetus found in Poland between 1996 and 2012 ( $F$ female, $M$ male, im immature, subad subadult, ad adult; voivodeships: VZach Zachodniopomorskie, VLub Lubuskie, VWar-Maz Warminsko-Mazurskie, VLodz Lodzkie)

Eagle Sex and Location (voivodeship, Collection Cause of death and additional information ID age district)
Assayed $\mathrm{THg}$ and $\mathrm{MeHg}(+)$ or THg only $( \pm)$

Liver Kidney Muscle Brain

\begin{tabular}{|c|c|c|c|c|c|c|c|c|}
\hline \multicolumn{9}{|c|}{ Haliaeetus albicilla $(n=22)$} \\
\hline HA-1 & $\mathrm{F}, \mathrm{im}$ & VZach, Goleniow & Jan 1996 & Unknown & + & + & + & + \\
\hline HA-2 & M, im & VZach, Police & Aug 2005 & Trauma (fractured wing) & + & + & + & + \\
\hline HA-3 & $\mathrm{F}, \mathrm{im}$ & VZach, Szczecin & Sept 2005 & Train collision; ringed in E Germany & + & + & + & \pm \\
\hline HA-4 & F, im $10 \mathrm{~ms}$ & VZach, Gryfino & Feb 2010 & $\begin{array}{l}\text { Electric fan collision, emaciated; ringed in } \mathrm{E} \\
\text { Germany, Brandenburg }\end{array}$ & + & + & + & + \\
\hline HA-5 & M, im & VWar-Maz, Ilawa & Mar 2011 & Disease & + & + & + & + \\
\hline HA-6 & M, subad & VZach, Bialogard & Feb 2009 & Trauma (broken leg) & + & + & + & + \\
\hline HA-7 & F, subad & VZach, Goleniow & Aug 2009 & Unknown & + & + & + & + \\
\hline HA-8 & $\begin{array}{l}\text { F, subad, } 5 \\
\text { ys }\end{array}$ & VZach, Gryfino & Mar 2010 & $\begin{array}{l}\text { Electric fan collision; ringed in E Germany, } \\
\text { Brandenburg }\end{array}$ & + & + & + & + \\
\hline HA-9 & M, ad & VZach, Lobez & Feb 1996 & Eagle attack & + & + & + & + \\
\hline HA-10 & M, ad & VZach, Gryfino & Aug 1996 & Unknown & + & + & + & \\
\hline HA-11 & $\mathrm{F}, \mathrm{ad}$ & VZach, Mysliborz & Nov 1998 & Unknown & + & + & + & \pm \\
\hline HA-12 & $\mathrm{F}$, ad & VZach, Goleniow & Feb 2007 & Unknown & + & + & + & + \\
\hline HA-14 & $\mathrm{F}$, ad & VLodz, Lowicz & Sep 2007 & Shot gun & + & + & + & \\
\hline HA-13 & $\mathrm{F}, \mathrm{ad}$ & VLodz, Laski & Dec 2007 & Shot gun & + & + & + & \\
\hline HA-15 & M, ad & VLodz, Lowicz & Nov 2007 & Unknown & + & + & + & \\
\hline HA-16 & $\begin{array}{l}\mathrm{F}, \mathrm{ad}, 16 \\
\mathrm{ys}\end{array}$ & VZach, Goleniow & Nov 2008 & Drowning, ringed in Poland & + & + & + & + \\
\hline HA-17 & $\mathrm{M}, \mathrm{ad}$ & VZach, Gryfino & May 2008 & Unknown (deformed beak) & + & + & + & + \\
\hline HA-18 & M, ad & VZach, Pyrzyce & Jan 2009 & Unknown & + & + & + & \\
\hline HA-19 & $\mathrm{F}, \mathrm{ad}$ & $\begin{array}{l}\text { VZach, Kamien } \\
\text { Pomorski }\end{array}$ & Mar 2009 & Electric fan collision & + & + & + & \\
\hline HA-20 & M, ad & VWar-Maz, Ilawa & Mar 2011 & Unknown & + & + & + & + \\
\hline HA-21 & $\mathrm{F}, \mathrm{ad}$ & VWar-Maz, Ostroda & Mar 2011 & Disease, emaciated & + & + & + & + \\
\hline HA-22 & M, ad & VWar-Maz, Ostroda & $\begin{array}{l}\text { April } \\
2012\end{array}$ & Unknown (suspected poisoning) & + & + & + & + \\
\hline \multicolumn{9}{|c|}{ Pandion haliaetus $(n=2)$} \\
\hline PH-1 & $\mathrm{F}, \mathrm{im}$ & VZach, Gryfice & Sep 2006 & Shot gun & + & + & + & + \\
\hline $\mathrm{PH}-2$ & $\mathrm{~F}, \mathrm{ad}$ & VZach, Gryfino & Sep 2003 & Trauma & + & + & + & + \\
\hline
\end{tabular}

The avian samples were dried to constant weight (at $55^{\circ} \mathrm{C}$ ) and then ground in the Planetary Mono Mill Pulverisette 6.

$\mathrm{MeHg}$ was determined in $\mathrm{KOH}$ extract using PDMS-GCPyr-AFS method described in details by Gorecki et al. (2013). The procedure was tested with the CRM DORM-2 (reference value of $\mathrm{MeHg}: 4.47 \pm 0.32 \mathrm{mg} \mathrm{kg}^{-1}$ ). The obtained $\mathrm{MeHg}$ concentration in the DORM-2 was $4.38 \pm 0.12 \mathrm{mg} \mathrm{kg}^{-1} \quad(n=4) \quad$ and $\quad \mathrm{OC} / \mathrm{RV}=97.99 \%$ (where OC and RV are obtained concentration and reference value, respectively). $\mathrm{THg}$ concentrations in the samples (in $\mathrm{KOH}$ extracts) were determined using an Automated Mercury Analyzer MA-3000 (Nippon Corporation).

\section{Statistical Analysis}

Statistical analyses were performed using StatSoft Statistica 9.1. Variation of the mean moisture among the avian tissues was evaluated by one-way ANOVA. Concentrations of $\mathrm{THg}$ and $\mathrm{MeHg}$ in the liver (L), kidney $(\mathrm{K})$, muscle (M) and brain (B) were expressed in dry weight (dw). The percentage of $\mathrm{MeHg}$ in $\mathrm{THg}(\% \mathrm{MeHg}=\mathrm{MeHg} / \mathrm{THg} \times$ 100) was also established. According to Norheim and Frøslie (1978), relative (to liver) concentrations of THg and $\mathrm{MeHg}$ were calculated as indices: $\mathrm{THgK} / \mathrm{THgL}, \mathrm{THgM} /$ THgL, THgB/THgL, MeHgK/MeHgL, MeHgM/MeHgL, 


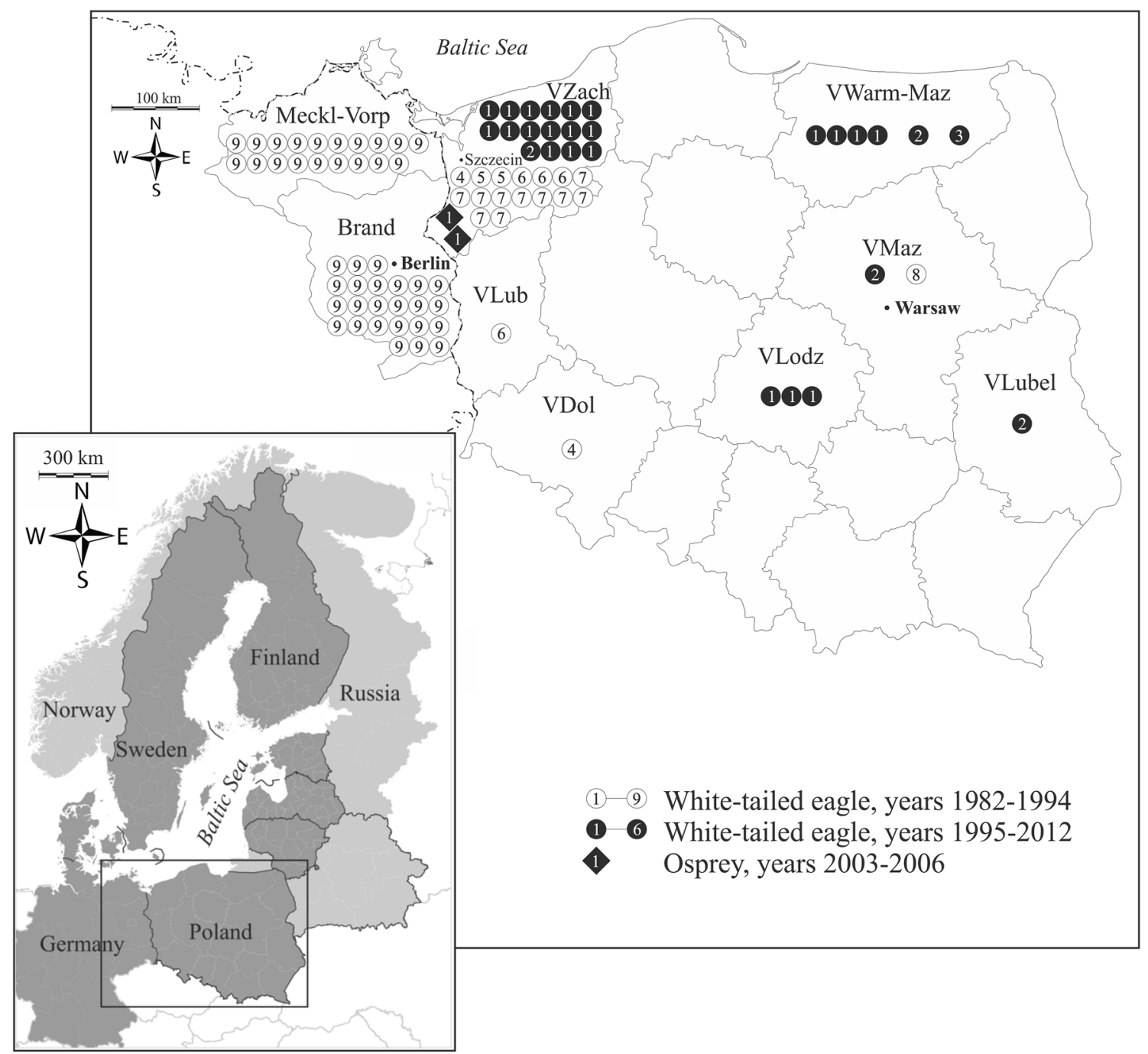

Fig. 1 Location and number (expressed by number of symbols) of the white-tailed eagle and osprey in which soft tissues mercury concentration was studied in Poland (VZach Voivodeship Zachodniopomorskie, VWar-Maz. V. Warminsko-Mazurskie, VLub V. Lubuskie, VDol V. Dolnoslaskie, VLodz V. Lodzkie, VMaz V. Mazowieckie, VLubel V. Lubelskie) and North-East Germany (Meckl-Vorp MecklenburgVorpommern, Brand Brandenburg) in years 1982-2012. Sources of data: 1. this study (black diamond and circles marked "1"); 2 . Komosa et al. (2009); 3. Kitowski et al. (2012); 4. Falandysz and Jakuczun (1986); 5. Falandysz et al. (1987); 6. Falandysz et al. (1988); 7. Falandysz et al. (2001); 8. Dittmann et al. (1990); 9. Kenntner et al. (2001)

$\mathrm{MeHgB/MeHgL}$. The Kolgomorov-Smirnov test with Lilliefors correction showed that the distribution of $\mathrm{THg}$ and $\mathrm{MeHg}$ concentrations in the eagle samples deviated from the expected normal distribution, and so in the statistical analysis the comparison of the mean concentrations of $\mathrm{Hg}$, non-parametric Kruskal-Wallis $(\mathrm{K}-\mathrm{W})$ or Mann-Whitney (M-W) tests were used when the number of means was respectively $\geq 3$ or equal 2 . Relationships between $\mathrm{Hg}$ concentrations among tissues and age group were evaluated by calculation of Spearman correlation coefficient $\left(r_{\mathrm{S}}\right)$. The correlation coefficients and differences in mean moisture, absolute and relative $\mathrm{Hg}$ concentrations among tissues, and $\mathrm{Hg}$ concentrations between age, genders and locations were considered statistically with an alpha level of 0.05. Since osprey samples came only from two specimens, interspecific comparison was not performed.

\section{RESULTS}

The water content in the liver, kidney, muscle and brain of the white-tailed eagle was 71.3, 75.3, 70.1 and $80.7 \%$, respectively, with significant differences between the tissues $(F=48.5$, df $=3, p<0.001)$. The exception was the relation between $\mathrm{L}$ and $\mathrm{M}$, with similar moisture. In the osprey tissues, the moisture was similar to that observed in the eagle. 
Table 2 Concentration of total mercury (THg) and methylmercury ( $\mathrm{MeHg}$ ) in $\mathrm{mg} \mathrm{kg}^{-1} \mathrm{dw}$ in soft tissues of the white-tailed eagle Haliaeetus albicilla and osprey Pandion haliaetus from various voivodeships of Poland (VZach Zachodniopomorskie, VWar-Maz. Warminsko-Mazurskie, $V L o d z$ Lodzkie, im immature, subad subadult, ad adult, Med median, AM arithmetic mean, SD standard deviation)

\begin{tabular}{|c|c|c|c|c|c|c|c|c|}
\hline \multirow{2}{*}{$\begin{array}{l}\text { Origin of individuals and age } \\
\text { group }\end{array}$} & \multicolumn{2}{|l|}{ Liver } & \multicolumn{2}{|l|}{ Kidney } & \multicolumn{2}{|l|}{ Muscle } & \multicolumn{2}{|l|}{ Brain } \\
\hline & $\mathrm{THg}$ & $\mathrm{MeHg}$ & $\mathrm{THg}$ & $\mathrm{MeHg}$ & $\mathrm{THg}$ & $\mathrm{MeHg}$ & $\mathrm{THg}$ & $\mathrm{MeHg}$ \\
\hline \multicolumn{9}{|l|}{ Haliaeetus albicilla } \\
\hline \multicolumn{9}{|l|}{ VZach: im } \\
\hline$n$ & 4 & 4 & 4 & 4 & 4 & 4 & 4 & 3 \\
\hline Med & 2.02 & 0.68 & 3.42 & 1.68 & 1.79 & 1.24 & 0.94 & 0.88 \\
\hline $\mathrm{AM} \pm \mathrm{SD}$ & $2.00 \pm 1.20$ & $0.90 \pm 0.84$ & $3.26 \pm 1.35$ & $1.46 \pm 0.94$ & $1.93 \pm 0.78$ & $1.25 \pm 0.62$ & $1.04 \pm 0.74$ & $0.84 \pm 0.53$ \\
\hline Range & $0.87-3.11$ & $0.15-2.10$ & $1.50-4.70$ & $0.25-2.23$ & $1.26-2.90$ & $0.69-1.81$ & $0.32-1.94$ & $0.29-1.34$ \\
\hline \multicolumn{9}{|l|}{ VZach: subad } \\
\hline$n$ & 3 & 3 & 3 & 3 & 3 & 3 & 3 & 3 \\
\hline Med & 2.01 & 2.01 & 3.36 & 0.96 & 0.97 & 0.64 & 0.56 & 0.34 \\
\hline $\mathrm{AM} \pm \mathrm{SD}$ & $1.63 \pm 0.79$ & $1.63 \pm 0.79$ & $2.70 \pm 1.50$ & $0.81 \pm 0.28$ & $1.15 \pm 0.46$ & $0.67 \pm 0.23$ & $0.73 \pm 0.32$ & $0.43 \pm 0.18$ \\
\hline Range & $0.72-2.16$ & $0.72-2.16$ & $0.99-3.76$ & $0.49-0.99$ & $0.81-1.68$ & $0.45-0.91$ & $0.54-1.10$ & $0.32-0.64$ \\
\hline \multicolumn{9}{|l|}{ VZach: ad } \\
\hline$n$ & 8 & 8 & 8 & 8 & 8 & 8 & 5 & 4 \\
\hline Med & 2.04 & 0.81 & 3.58 & 0.73 & 0.93 & 0.43 & 0.62 & 0.34 \\
\hline $\mathrm{AM} \pm \mathrm{SD}$ & $1.96 \pm 1.21$ & $1.14 \pm 1.08$ & $4.33 \pm 4.07$ & $1.09 \pm 1.06$ & $1.41 \pm 0.98$ & $0.69 \pm 0.50$ & $0.96 \pm 1.04$ & $0.47 \pm 0.44$ \\
\hline Range & $0.46-3.94$ & $0.15-3.19$ & $0.54-13.14$ & $0.20-2.94$ & $0.37-3.01$ & $0.17-1.59$ & $0.15-2.67$ & $0.11-1.08$ \\
\hline \multicolumn{9}{|l|}{ VZach: im + subad + ad } \\
\hline$n$ & 15 & 15 & 15 & 15 & 15 & 15 & 12 & 10 \\
\hline Med & 2.03 & 0.69 & 3.36 & 0.99 & 1.25 & 0.69 & 0.59 & 0.86 \\
\hline $\mathrm{AM} \pm \mathrm{SD}$ & $1.91 \pm 1.07$ & $1.05 \pm 0.90$ & $3.72 \pm 3.08$ & $1.13 \pm 0.90$ & $1.50 \pm 0.85$ & $0.84 \pm 0.53$ & $0.93 \pm 0.76$ & $1.32 \pm 1.19$ \\
\hline Range & $0.46-3.94$ & $0.15-3.19$ & $0.54-13.14$ & $0.20-2.94$ & $0.37-3.01$ & $0.17-1.81$ & $0.15-2.67$ & $0.19-4.60$ \\
\hline \multicolumn{9}{|l|}{ VWar-Maz: im } \\
\hline$n=1$ & 0.61 & 0.60 & 1.14 & 0.64 & 0.30 & 0.30 & 0.25 & 0.25 \\
\hline \multicolumn{9}{|l|}{ VWar-Maz: ad } \\
\hline$n$ & 3 & 3 & 3 & 3 & 3 & 3 & 3 & 3 \\
\hline Med & 0.62 & 0.37 & 1.11 & 0.34 & 0.45 & 0.45 & 0.41 & 0.21 \\
\hline $\mathrm{AM} \pm \mathrm{SD}$ & $1.02 \pm 0.88$ & $0.75 \pm 0.65$ & $1.21 \pm 0.92$ & $0.43 \pm 0.34$ & $0.71 \pm 0.54$ & $0.45 \pm 0.30$ & $0.55 \pm 0.43$ & $0.31 \pm 0.21$ \\
\hline Range & $0.40-2.03$ & $0.37-1.50$ & $0.34-2.18$ & $0.15-0.81$ & $0.36-1.33$ & $0.15-0.75$ & $0.21-1.03$ & $0.17-0.56$ \\
\hline \multicolumn{9}{|l|}{ VWar-Maz: im + ad } \\
\hline$n$ & 4 & 4 & 4 & 4 & 4 & 4 & 4 & 4 \\
\hline Med & 0.61 & 0.48 & 1.13 & 0.49 & 0.41 & 0.38 & 0.33 & 0.23 \\
\hline $\mathrm{AM} \pm \mathrm{SD}$ & $0.92 \pm 0.75$ & $0.71 \pm 0.54$ & $1.19 \pm 0.76$ & $0.48 \pm 0.30$ & $0.61 \pm 0.48$ & $0.41 \pm 0.26$ & $0.47 \pm 0.38$ & $0.30 \pm 0.18$ \\
\hline Range & $0.40-2.03$ & $0.37-1.50$ & $0.34-2.18$ & $0.15-0.81$ & $0.30-1.33$ & $0.15-0.75$ & $0.21-1.03$ & $0.17-0.56$ \\
\hline \multicolumn{9}{|l|}{ VLodz: ad } \\
\hline$n$ & 3 & 3 & 3 & 3 & 3 & 3 & & \\
\hline Med & 1.30 & 1.25 & 3.55 & 1.01 & 1.19 & 0.35 & & \\
\hline $\mathrm{AM} \pm \mathrm{SD}$ & $3.76 \pm 4.91$ & $2.68 \pm 3.09$ & $17.7 \pm 26.0$ & $3.21 \pm 4.19$ & $2.91 \pm 3.77$ & $1.72 \pm 2.43$ & & \\
\hline Range & $0.57-9.41$ & $0.57-6.23$ & $1.81-47.6$ & $0.30-7.23$ & $0.30-7.23$ & $0.29-4.53$ & & \\
\hline \multicolumn{9}{|c|}{ All individuals: VZach + VWar-Maz + VLodz } \\
\hline$n$ & 22 & 22 & 22 & 22 & 22 & 22 & 16 & 14 \\
\hline Med & 1.65 & 0.67 & 2.87 & 0.89 & 1.08 & 0.55 & 0.56 & 0.33 \\
\hline $\mathrm{AM} \pm \mathrm{SD}$ & $1.98 \pm 1.95$ & $1.21 \pm 1.36$ & $5.16 \pm 9.87$ & $1.30 \pm 1.70$ & $1.53 \pm 1.52$ & $0.88 \pm 0.95$ & $0.82 \pm 0.70$ & $0.49 \pm 0.37$ \\
\hline Range & $0.40-9.41$ & $0.15-6.23$ & $0.34-47.6$ & $0.15-8.05$ & $0.30-7.23$ & $0.15-4.53$ & $0.15-2.67$ & $0.11-1.34$ \\
\hline
\end{tabular}


Table 2 continued

\begin{tabular}{|c|c|c|c|c|c|c|c|c|}
\hline \multirow{2}{*}{$\begin{array}{l}\text { Origin of individuals and age } \\
\text { group }\end{array}$} & \multicolumn{2}{|l|}{ Liver } & \multicolumn{2}{|l|}{ Kidney } & \multicolumn{2}{|l|}{ Muscle } & \multicolumn{2}{|l|}{ Brain } \\
\hline & $\mathrm{THg}$ & $\mathrm{MeHg}$ & $\mathrm{THg}$ & $\mathrm{MeHg}$ & $\mathrm{THg}$ & $\mathrm{MeHg}$ & $\mathrm{THg}$ & $\mathrm{MeHg}$ \\
\hline \multicolumn{9}{|l|}{ Pandion haliaetus } \\
\hline \multicolumn{9}{|l|}{ VZach: im } \\
\hline$n=1$ & 3.65 & 2.33 & 4.03 & 3.25 & 2.00 & 1.71 & 0.33 & 0.32 \\
\hline \multicolumn{9}{|l|}{ VZach: ad } \\
\hline$n=1$ & 7.11 & 3.76 & 5.26 & 3.98 & 3.51 & 3.23 & 0.65 & 0.61 \\
\hline \multicolumn{9}{|l|}{ VZach: im + ad } \\
\hline$n$ & 2 & 2 & 2 & 2 & 2 & 2 & 2 & 2 \\
\hline Med & 5.38 & 3.04 & 4.64 & 3.62 & 2.75 & 2.47 & 0.49 & 0.46 \\
\hline $\mathrm{AM} \pm \mathrm{SD}$ & $5.38 \pm 2.45$ & $3.04 \pm 1.01$ & $4.65 \pm 0.87$ & $3.62 \pm 0.52$ & $2.75 \pm 1.07$ & $2.47 \pm 1.07$ & $0.49 \pm 0.23$ & $0.47 \pm 0.21$ \\
\hline Range & $3.65-7.11$ & $2.33-3.76$ & $4.03-5.26$ & $3.25-3.98$ & $2.00-3.51$ & $1.71-3.23$ & $0.33-0.65$ & $0.32-0.61$ \\
\hline
\end{tabular}

\section{White-Tailed Eagle}

Concentrations of $\mathrm{THg}$ and $\mathrm{MeHg}$ in the white-tailed eagle samples were within $0.15-47.6$ and $0.11-8.05 \mathrm{mg} \mathrm{kg}^{-1}$, respectively (Table 2). The greatest variability was found for $\mathrm{THg}$ and $\mathrm{MeHg}$ concentrations in the kidney, and the lowest in the brain. In 3 livers and 10 kidneys, concentrations exceeded $3 \mathrm{mgTHg} \mathrm{kg}^{-1}$. In comparisons of $\mathrm{THg}$ and $\mathrm{MeHg}$ in the liver, kidney, muscle and brain, no significant differences were found between the age groups and between the birds coming from various voivodeships. In the whole, white-tailed eagle group medians of $\mathrm{THg}$ and $\mathrm{MeHg}$ concentrations were in descending order: $\mathrm{K}>\mathrm{L}>\mathrm{M}>\mathrm{B}$ (Table 2). Unlike MeHg, differences were statistically confirmed between $\mathrm{THg}$ concentrations in the tissues $(\mathrm{K}-\mathrm{W}$ test: $H=20.06, \mathrm{df}=3, p<0.001)$ and concerned the following pairs of tissues: $\mathrm{K}-\mathrm{M}, \mathrm{K}-\mathrm{B}$ and $\mathrm{L}-\mathrm{B}$. Although nephric THg concentration was almost twice as high as the liver, $\mathrm{MeHg}$ concentrations in these organs were very similar, as confirmed by the ratio $\mathrm{MeHgK} / \mathrm{MeHgL}=1$. Respectively, in the brain and muscle, $\mathrm{THg}$ and $\mathrm{MeHg}$ concentrations were $\sim 0.5$ and $\sim 0.7-0.8$ of values recorded in the liver (Table 3 ). In all tissues of the white-tailed eagle, significant correlations $(p<0.001)$ between $\mathrm{THg}$ and $\mathrm{MeHg}$ concentrations were found (L: 0.721, M: 0.733, M: 0.926, B: 0.934).

No differences in \% MeHg related to age or place of origin of the white-tailed eagles were found but a certain trend for hepatic \% MeHg was observed (K-W test: $H=6.0, \mathrm{df}=2$, $p<0.06)$. The greatest $\% \mathrm{MeHg}$ was detected in the liver of VLodz individuals and less in birds from VWar-Maz and VZach $(96,74,55 \%$, respectively). The order of $\% \mathrm{MeHg}$ medians in the tissues coming from all eagles was as following: $\mathrm{L}>\mathrm{B}>\mathrm{M}>\mathrm{K}$ (Fig. 2) and the samples differed in $\% \mathrm{MeHg}(\mathrm{K}-\mathrm{W}$ test: $H=16.8, \mathrm{df}=3, p<0.001)$. In the kidney, $\% \mathrm{MeHg}$ was significantly lower $(30.5 \%)$ than in the other tissues where medians were similar, from $51 \%$ in the brain to $67 \%$ in the liver.

Across the age groups, only the $\mathrm{MeHgK} / \mathrm{MeHgL}$ index varied significantly (K-W test: $H=6.5, \mathrm{df}=2, p<0.05)$. The values of this index among immatures, subadults and adults were as follows: $1.65,0.75$ and 0.94 . The value in immatures proved to be much greater than adults, which was further confirmed by the $\mathrm{M}-\mathrm{W}$ test $(U=8.0$, $p<0.05$ ). No statistical difference was observed between immatures and subadults due to low numbers of compared individuals (5 and 3, respectively).

\section{Osprey}

In osprey, higher concentrations of $\mathrm{THg}$ and $\mathrm{MeHg}$ were found in samples coming from the adult than the immature (Table 2). The percentage of MeHg in THg in liver, kidney, muscle and brain was $58 \%$ (range 53-64\%), $78 \%$ (range 76-81\%), $88 \%$ (range 85-92\%) 95\% (range 94-97\%), respectively. Values of the other indicators are shown in Table 3. Only one of the indicators was $>1(\mathrm{MeHgK} / \mathrm{Me}-$ $\mathrm{HgL}=1.23$ ), the others were $<1$.

\section{DISCUSSION}

In ecotoxicological reports, $\mathrm{THg}$ and $\mathrm{MeHg}$ concentrations are usually expressed per dry or wet weight, and therefore it is important to determine the water contents in the samples. However, such data are not often published for Falconiformes. Some authors assume $80 \%$ moisture for all soft tissues or $70 \%$ for the most frequently investigated liver (Hopkins et al. 2007; Rutkiewicz et al. 2011). Our study indicated that tissues of the white-tailed eagle do differ in water content, confirming the previous results of 
Table 3 Indices concerning relations between $\mathrm{THg}$ and $\mathrm{MeHg}$ tissue concentrations in relation to $\mathrm{THg}$ and $\mathrm{MeHg}$ concentrations in liver in the white-tailed eagle Haliaeetus albicilla and osprey Pandion haliaetus found in Poland ( $L$ liver, $K$ kidney, $M$ muscle, $B$ brain, $M e d$ median, $A M$ arithmetic mean, $S D$ standard deviation)

\begin{tabular}{|c|c|c|c|c|c|c|}
\hline Species & $\mathrm{THgK} / \mathrm{THgL}$ & $\mathrm{MeHgK} / \mathrm{MeHgL}$ & $\mathrm{THgM} / \mathrm{THgL}$ & $\mathrm{MeHgM} / \mathrm{MeHgL}$ & $\mathrm{THgB} / \mathrm{THgL}$ & $\mathrm{MeHgB} / \mathrm{MeHgL}$ \\
\hline \multicolumn{7}{|c|}{ Haliaeetus albicilla } \\
\hline$n$ & 22 & 22 & 22 & 22 & 16 & 14 \\
\hline Med & 1.77 & 1.00 & 0.78 & 0.70 & 0.51 & 0.49 \\
\hline $\mathrm{AM} \pm \mathrm{SD}$ & $2.19 \pm 1.44$ & $1.13 \pm 0.63$ & $0.84 \pm 0.34$ & $1.09 \pm 1.04$ & $0.50 \pm 0.17$ & $0.71 \pm 0.56$ \\
\hline Range & $0.75-5.66$ & $0.41-3.43$ & $0.37-1.62$ & $0.19-4.60$ & $0.26-0.86$ & $0.36-2.06$ \\
\hline \multicolumn{7}{|c|}{ Pandion-haliaetus } \\
\hline$n$ & 2 & 2 & 2 & 2 & 2 & 2 \\
\hline Med & 0.92 & 1.23 & 0.52 & 0.80 & 0.09 & 0.15 \\
\hline $\mathrm{AM} \pm \mathrm{SD}$ & $0.92 \pm 0.26$ & $1.23 \pm 0.24$ & $0.52 \pm 0.04$ & $0.80 \pm 0.09$ & $0.09 \pm 0.00$ & $0.15 \pm 0.02$ \\
\hline Range & $0.74-1.10$ & $1.06-1.39$ & $0.49-0.55$ & $0.73-0.86$ & $0.09-0.09$ & $0.14-0.16$ \\
\hline
\end{tabular}

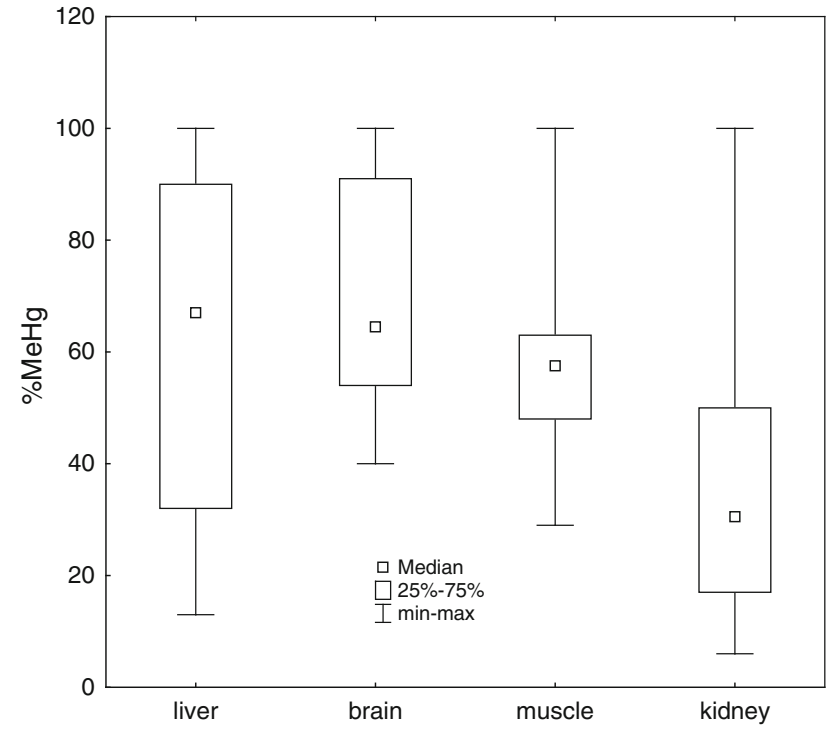

Fig. 2 Percentage of $\mathrm{MeHg}$ in $\mathrm{THg}(\% \mathrm{MeHg})$ in tissues of the whitetailed eagle found in Poland between 1996 and 2012

Falandysz et al. (1988) and Kalisinska et al. (2006). We propose, for $\mathrm{Hg}$ concentrations in Falconiformes, using soft tissues conversion rates that take into account differences in the tissue moisture (liver $70 \%$, kidney $75 \%$, muscle $70 \%$, brain $80 \%$ ).

In the EU, soft tissue samples of protected birds usually come from dead specimens sporadically found in the field (Kenntner et al. 2001; Lemarchand et al. 2012). Given the fact that $\mathrm{Hg}$ is incorporated into feathers only during their growth, and in falconiformes, feathers are shed gradually, and some as late as in the 3-4 years of life, $\mathrm{Hg}$ determined in feathers may come from a few weeks before or even dozens of months before, depending on the age of the individual and the stage of moulting (Johnels and Westermark 1969; DesGranges et al. 1998). Half-life of $\mathrm{Hg}$ in avian soft tissues is estimated to least 1-2 months, but depends on the amount and $\mathrm{Hg}$ species intaken with food$\mathrm{MeHg}$ has a longer biological lifetime than InHg. That is why the liver and kidney are treated as important materials that reflect mid-term exposure to Hg (Hopkins et al. 2007; Scheuhammer et al. 2007).

Based on literature data (including white-tailed eagle), Shore et al. (2011) proposed indicative values of THg for the liver, kidney and brain of non-marine birds which may result in death at: $>20,>40$ and $>15$ (in adult) $\mathrm{mg} \mathrm{kg}^{-1} \mathrm{ww}$ (or $>67,>160$, and $>75 \mathrm{mg} \mathrm{kg}^{-1} \mathrm{dw}$ ), respectively. Presently, such high lethal values of $\mathrm{Hg}$ concentrations in soft tissues (including the very seldom investigated brain) of the osprey, white-tailed eagle and its North American counterpart bald eagle are rarely recorded. In brains of those birds, THg concentrations even $>10 \mathrm{mg} \mathrm{kg}^{-1} \mathrm{dw}$ were observed sporadically both in Europe and North America, although in extremely rare case they reached $75 \mathrm{mg} / \mathrm{kg}$ (Jensen et al. 1972; Holt et al. 1979; Rutkiewicz et al. 2011). Unlike the brain, THg in the liver and kidney is frequently analysed. Hepatic and/or kidney investigations of European white-tailed eagles that found dead in the field curried out in the 1960-1980s $(n=85)$ and after 1990 ( $n=102$, including our results) revealed about 25 and $4 \%$ of cases of mercury poisoning (Table 4). This comparison indicates a decrease in lethal $\mathrm{Hg}$ intoxication among whitetailed eagles in Europe over the last decades.

Also Shore et al. (2011) proposed hepatic THg concentrations associated with adverse effects on avian reproduction ( $>2 \mathrm{mg} \mathrm{kg}^{-1}$ ww or $>6.7 \mathrm{mg} \mathrm{kg}^{-1} \mathrm{dw}$ ). Only one of our 22 white-tailed eagles had a liver concentration $>6.7 \mathrm{mgHg} \mathrm{kg}^{-1}$ (from VLodz) but 3 of 57 individuals collected in Austria and Germany (Kenntner et al. 2001). In our and Austro-German studies, the maximum values and medians of hepatic THg concentration were similar (9.4 vs. 12 and 1.6 vs. $1.2 \mathrm{mg} \mathrm{kg}^{-1} \mathrm{dw}$, respectively; Table 4). 
Table 4 Concentration of total mercury ( $\mathrm{mg} \mathrm{kg}^{-1} \mathrm{dw}$ ) in soft tissues of white-tailed eagle and osprey investigated in Europe (age categories: nestl nestling, juv juvenile, im immature, $a d$ adult, un unknown, $n$ range, Med median, $A M$ arithmetic mean, $d l$ detection limit)

\begin{tabular}{|c|c|c|c|c|c|c|}
\hline Localisation and time & Age & Liver & Kidney & Muscle & Brain & References \\
\hline \multicolumn{7}{|c|}{ White-tailed eagle Haliaeetus albicilla } \\
\hline \multicolumn{2}{|l|}{ Finland, 1965} & $n=5 ; 40-90$ & $n=5 ; 196-480$ & $\begin{array}{l}n=5 \\
\quad 6.3-28.3\end{array}$ & & *Henriksson et al. (1966) \\
\hline \multirow{4}{*}{$\begin{array}{l}\text { Germany, W, } 1969 \\
\text { Germany, NE, } \\
1967-1976\end{array}$} & \multirow{4}{*}{$\begin{array}{l}\text { ad } \\
\text { im-ad }\end{array}$} & $n=1 ; 161$ & $n=1 ; 106$ & & & *Koeman et al. (1972) \\
\hline & & & & & & *Oehme (1981) \\
\hline & & $\begin{array}{l}n=25 \\
\quad<\mathrm{dl}-25\end{array}$ & $\begin{aligned} n & =23 \\
& <\mathrm{dl}-57\end{aligned}$ & & & \\
\hline & & Med 2.7 & Med 23 & & & \\
\hline \multirow[t]{2}{*}{ 1976-1978 } & & $\begin{array}{l}n=10 \\
16-445\end{array}$ & $n=10 ; 24-1224$ & & & \\
\hline & & Med 303 & Med 462 & & & \\
\hline Sweden, 1965-1969 & un & & & $n=7 ; 0.5-87$ & $n=5 ; 5.5-70$ & *Jensen et al. (1972) \\
\hline \multirow[t]{2}{*}{ Norway, 1972-1977 } & un & $n=24 ; 1.0-53$ & $\begin{array}{l}n=24 \\
\quad 1.2-220\end{array}$ & $\begin{array}{l}n=24 \\
0.3-12\end{array}$ & & *Norheim and Frøslie (1978) \\
\hline & & Med 11 & Med 14 & Med 2.3 & & \\
\hline \multirow[t]{2}{*}{ Norway, 1965-1976 } & un & $\begin{aligned} n & =25 \\
& <\mathrm{dl}-53\end{aligned}$ & $\begin{aligned} n & =27 \\
& <\mathrm{dl}-220\end{aligned}$ & $\begin{array}{l}n=27 \\
\quad<\mathrm{dl}-13\end{array}$ & $n=6 ; 1.0-10$ & *Holt et al. (1979) \\
\hline & & Med 8.0 & Med 14 & Med 2.3 & Med 4.0 & \\
\hline Poland, 1982 & un & $n=1 ; 30$ & & $n=1 ; 2.8$ & & Falandysz and Jakuczun (1986) \\
\hline \multirow[t]{2}{*}{ Poland, 1984} & im & $n=1 ; 3.3$ & $n=1 ; 24$ & $n=1 ; 0.87$ & & *Falandysz et al. (1987) \\
\hline & ad & $n=1 ; 37$ & $n=1 ; 176$ & $n=1 ; 1.1$ & & \\
\hline Poland, 1986-1987 & ad & $n=4 ; 2.9-110$ & $n=4 ; 10-224$ & $n=4 ; 1.6-21$ & $n=1 ; 4.2$ & *Falandysz et al. (1988) \\
\hline Poland, 1987 & ad & & & $n=1 ; 9.0$ & & Dittmann et al. (1990) \\
\hline \multirow[t]{2}{*}{ Poland, 1991-1995 } & im-ad & $n=8 ; 0.6-21$ & $n=10 ; 1.4-220$ & $\begin{array}{l}n=8 \\
0.02-5.6\end{array}$ & & Falandysz et al. (2001) \\
\hline & & AM 5.8 & AM 52 & AM 1.8 & & \\
\hline \multirow[t]{2}{*}{$\begin{array}{l}\text { Germany and Austria, } \\
1993-2000\end{array}$} & im-ad & $\begin{array}{l}n=57 \\
0.03-12\end{array}$ & $\begin{array}{l}n=57 \\
0.3-144\end{array}$ & & & *Kenntner et al. (2001) \\
\hline & & Med 1.2 & Med 3.4 & & & \\
\hline \multirow[t]{2}{*}{ Finland, 1994-2001 } & im-ad & $n=9 ; 4.6-30$ & $\begin{array}{l}n=8 \\
\quad 11.3-211\end{array}$ & & & *Krone et al. (2006) \\
\hline & & Med 10 & Med 28 & & & \\
\hline \multirow[t]{2}{*}{ Greenland, 1997-2000 } & juv-ad & $n=11 ; 1.9-19$ & $n=12 ; 2.6-14$ & & & *Krone et al. (2004) \\
\hline & & Med 4.7 & Med 6.6 & & & \\
\hline Poland, 2005-2007 & $\mathrm{ad}$ & & $\begin{array}{l}n=4 ; 0.4-4.3 \\
\text { AM } 1.5\end{array}$ & & & Komosa et al. (2009) \\
\hline Poland, 2007 & ad & & $n=1 ; 3.5$ & & & Kitowski et al. (2012) \\
\hline \multirow[t]{2}{*}{ Poland, 1995-2012 } & im, ad & $\begin{array}{l}n=22 \\
0.4-9.4\end{array}$ & $n=22 ; 0.3-48$ & $\begin{array}{l}n=22 \\
0.3-7.2\end{array}$ & $\begin{array}{l}n=16 \\
0.1-2.7\end{array}$ & This study \\
\hline & & Med 1.6 & Med 2.9 & Med 1.1 & Med 0.6 & \\
\hline \multicolumn{7}{|l|}{ Osprey Pandion haliaetus } \\
\hline Norway, 1972-1977 & un & $\begin{array}{l}n=8 ; 2.7-60 \\
\text { Med } 15\end{array}$ & $\begin{array}{l}n=8 ; 9.6-180 \\
\text { Med } 17\end{array}$ & $\begin{array}{l}n=8 ; 1.7-9.3 \\
\text { Med } 4.7\end{array}$ & & *Norheim and Frøslie (1978) \\
\hline Norway, 1965-1976 & un & $\begin{array}{l}n=10 ; 2.0-60 \\
\text { Med } 9.3\end{array}$ & $\begin{array}{l}n=8 ; 2.4-180 \\
\text { Med } 17\end{array}$ & $\begin{array}{l}n=9 ; 1.3-9.3 \\
\text { Med } 3.3\end{array}$ & $\begin{array}{l}n=6 ; 1.0-8.5 \\
\text { Med } 4.5\end{array}$ & *Holt et al. (1979) \\
\hline Finland, 1970-1972 & nestl & $n=2 ; 0.8-7.1$ & $n=3 ; 0.8-6.8$ & $n=3 ; 0.5-3.4$ & $n=3 ; 0.4-2.9$ & Häkkinen and Häsänen (1980) \\
\hline France, 2007 & juv-ad & $\begin{array}{l}n=14 ;<\mathrm{dl}-54 \\
\text { AM } 11\end{array}$ & & & & *Lemarchand et al. (2012) \\
\hline
\end{tabular}


Table 4 continued

\begin{tabular}{lllllll}
\hline Localisation and time & Age & Liver & Kidney & Muscle & Brain & References \\
\hline Poland, 2003-2006 & im, ad & $\begin{array}{l}n=2 ; 3.6-7.1 \\
\text { Med 5.4 }\end{array}$ & $\begin{array}{l}n=2 ; 4.0-5.3 \\
\text { Med 4.6 }\end{array}$ & $\begin{array}{l}n=2 ; 2.0-3.5 \\
\text { Med 2.7 }\end{array}$ & $\begin{array}{l}n=2 ; 0.3-0.6 \\
\text { Med 0.5 }\end{array}$ & This study \\
\end{tabular}

* Original data in wet weight; in the recalculations on the dry weight was assumed 70, 75, 70, and $80 \%$ moisture liver, kidney, muscle, and brain, respectively

Among southern Baltic countries, the largest number of white-tailed eagles nest in eastern Germany and northern Poland (Hauff and Mizera 2006). That is why studies in border areas in Poland and Germany have given most data on $\mathrm{Hg}$ in this species. In Kenntner et al. (2001), 43 of 57 (75\%) specimens came from eastern Germany (Fig. 1). Eagles in the border area range freely across tens of kilometres (Hauff and Mizera 2006; Table 1). Moreover, in eastern Germany and Poland, Hg-pesticides were banned at a similar time (Kenntner et al. 2001). For these reasons, the results of mentioned authors and our findings show many similarities. In the white-tailed eagles from Germany and Poland, higher THg concentrations were found in the dried kidney than the liver (Germany: 3.4 vs. $1.2 \mathrm{mg} \mathrm{kg}^{-1}$, Poland: 2.9 vs. $1.6 \mathrm{mg} \mathrm{kg}^{-1}$, respectively). In 26 German eagles, THg residues were $\sim 3.3 \mathrm{ppm}$ in the liver, kidney, or both, but only one had $\mathrm{THgK} / \mathrm{THgL} \leq 1$. Thus, $46 \%$ of the birds had a value of this index $\geq 1$ (Kenntner et al. 2001). In the Polish group of white-tailed eagles, 10/22 individuals $(45 \%)$ had an index $>1$. In the German and Polish eagles with lower THg concentrations $(<3.3 \mathrm{ppm})$ in the organs, such strong differences were not found between hepatic and nephric THg concentrations. However, those concentrations significantly correlated with each other in both studies.

In comparison to the German and Polish studies, whitetailed eagles in Finland and Greenland (collected between 1994 and 2001) had THg concentrations 5 and 2 times higher in the liver, and 9 and 2 times higher in the kidney (Table 4). Such large differences between the Polish-German and Finnish populations could have resulted from three main factors in the Finnish population: age (domination of older individuals), the site (Baltic coast and islands) and diet composition and origin, mostly marine fish and aquatic birds associated with Hg-contaminated water bodies (Krone et al. 2006). In the case of the Greenland population, the increased accumulation of $\mathrm{Hg}$ in the white-tailed eagles may have resulted from their diet of marine origin (seabirds and fish) with a naturally high content of $\mathrm{Hg}$ (Krone et al. 2004). Compared to the Finnish and Greenland populations, eagles living in the Poland and Germany have a more inland character and inhabit mainly south Baltic areas rich in lakes and forests, and minimally contaminated with $\mathrm{Hg}$. Eagles in these areas benefit from a more varied diet, including fish, waterfowl, and carrion (Kenntner et al. 2001).

In Europe, data on $\mathrm{Hg}$ in osprey's soft tissues are extremely scarce. In four papers were investigated 35 ospreys in total. Both before 1980 and after 2000, in single ospreys examined in Norway and France, high hepatic THg concentrations (50-60 mg kg ${ }^{-1} \mathrm{dw}$ ) were reported, which could have contributed to their death (Table 4).

In some papers on piscivorous Falconiformes, relations between the age and tissue $\mathrm{Hg}$ concentration were found. For example, positive correlations were revealed between age and kidney or brain THg concentrations in the whitetailed eagle and bald eagle, respectively (Krone et al. 2006; Rutkiewicz et al. 2011). Moreover, Krone et al. (2004) showed a greater concentration of nephric $\mathrm{THg}$, but not hepatic THg, in adult white-tailed eagles than the younger, and suggested that the higher $\mathrm{Hg}$ level in the kidney than the liver was caused by a long-term accumulation in the kidney, mainly as InHg. In the liver of ospreys from France, Lemarchand et al. (2012) revealed a significant increase of THg concentrations between non-flying juveniles and subadults or adults, and a significant decrease between subadult and adult groups. A study on osprey from the U.S. showed agedependent relationships between THg concentrations in the liver and kidney. Generally, adults had higher and more variable $\mathrm{THg}$ residues than chicks and hatch-year ospreys (Hopkins et al. 2007). In our white-tailed eagles, correlations between age and the $\mathrm{Hg}$ tissue concentrations were not significant. This discrepancy in the results is likely to depend on the intensity of the transfer of $\mathrm{MeHg}$ to feathers during their growth (especially in chicks), the level of accumulated $\mathrm{Hg}$ and the efficiency of $\mathrm{MeHg}$ demethylation. Ratios between $\mathrm{MeHg}$ and $\mathrm{InHg}$ change dynamically in avian soft tissues, and are conditioned by the amount of $\mathrm{MeHg}$ intake and absorption in the intestine, tissue concentrations, and the ability to demethylate and excrete $\mathrm{Hg}$. Especially, in fish-eating birds, there are significant interspecific and interindividual differences in the intensity of MeHg demethylation (Gochfeld 2003; Scheuhammer et al. 2008). Therefore, information on hepatic and nephric THg concentrations is not sufficient for diagnosing $\mathrm{MeHg}$ toxicity in birds (Scheuhammer et al. 2007; Rutkiewicz et al. 
2011). Kidney $\mathrm{THg}$ concentrations are known to represent mainly $\mathrm{InHg}$, and $\mathrm{THgK} / \mathrm{THgL} \geq 2$ proves such exposure (Scheuhammer et al. 1998; Gochfeld 2003). However, if nephric and hepatic THg concentrations are low, as in the majority of birds examined in this study, then $\mathrm{THgK} / \mathrm{THgL}$ may be $<2$. In our eagle group, $\mathrm{THgK} / \mathrm{THgL}=1.8$ and $\mathrm{MeHgK} / \mathrm{MeHgL}=1$ but $\% \mathrm{MeHg}$ was over two times higher in the liver than kidney (67 vs. $30 \%$ ). In the muscle and brain, $\% \mathrm{MeHg}$ levels were similar $(\sim 60 \%)$ and both significantly differed from nephric level (Fig. 2). Norheim and Frøslie (1978), based on kidney THg residues, divided white-tailed eagles from Norway into two groups: I $(n=7)$, and II $(n=5)$. Nephric concentration in the group I was below $33 \mathrm{mgHg} \mathrm{kg}^{-1} \mathrm{dw}$ and in group II was above that level. The hepatic and nephric medians in the group I were similar $\left(\sim 7 \mathrm{mgHg} \mathrm{kg}^{-1}\right)$ but in muscle much lower $\left(1.3 \mathrm{mgHg} \mathrm{kg}^{-1}\right)$. Index $\% \mathrm{MeHg} / \mathrm{THg}$ in the tissues was in the range 48-59\% with the lowest and highest values in the liver and muscle. In the group II, THg concentrations in all tissues were higher $\left(16,88,3.7 \mathrm{mg} \mathrm{kg}^{-1}\right)$ but the lowest and highest values of $\% \mathrm{MeHg}$ had the kidney (7\%) and muscle $(65 \%)$, intermediate the liver $(37 \%)$. Although the Norwegian eagles from groups I and II hepatic and nephric $\mathrm{THg}$ concentrations were 4.5/10 and 2.5/30 times greater than in analogous tissues of the Polish samples, differences in $\% \mathrm{MeHg}$ were more ambiguous. The lowest hepatic $\% \mathrm{MeHg}(37 \%)$ was observed in eagles from group II (with high median: $\left.16 \mathrm{mgTHg} \mathrm{kg}^{-1}\right)$ and Polish individuals ( $\sim 48$ and 67\%) with lower medians (7.3 and $1.6 \mathrm{mgTHg} \mathrm{kg}{ }^{-1}$, respectively). In bald eagles from North America, hepatic mean $\mathrm{THg}$ concentrations ranged from 7 to $14 \mathrm{mg} \mathrm{kg}^{-1} \mathrm{dw}$ (Weech et al. 2003; Rutkiewicz et al. 2011), alike in white-tailed eagles from group I investigated in Norway, and much greater than the hepatic $\mathrm{THg}$ concentration in our eagles $\left(<2 \mathrm{mg} \mathrm{kg}^{-1}\right)$. The mean fraction of $\mathrm{MeHg}$ in the liver of the bald eagle and white-tailed eagle from the group I was similar (50-60\%), but in the whitetailed eagles from 1996 to 2012, it was higher (67\%). The cited and compared above values of $\mathrm{THg}$ and $\% \mathrm{MeHg}$ in both eagle species confirm observations by various authors who report that the increasing concentration of $\mathrm{THg}$ in avian liver is accompanied by a decrease in \% $\mathrm{MeHg}$ in this organ. However, negative correlations between hepatic $\mathrm{THg}$ and \% MeHg have not always been observed (Scheuhammer et al. 1998; Weech et al. 2003).

Comparing the species in analogous age categories, in the eagle species, lower $\mathrm{Hg}$ concentrations in the liver and/ or kidney were generally found than in the osprey investigated in Europe and North America (Norheim and Frøslie 1978; Weech et al. 2003; Scheuhammer et al. 2007; Hopkins et al. 2007; Lemarchand et al. 2012). It may partly arise from differences in their diets. Both white-tailed eagle and bald eagle are opportunistic feeders but osprey is obligatory fish-eating predator, so is more susceptible to the accumulation of $\mathrm{Hg}$.

Out of 13 ospreys collected in France and Poland in 2000s, seven (54\%) had a hepatic $\mathrm{THg}$ concentration associated with an adverse effect on avian reproduction. Hepatic $\mathrm{THg}$ concentrations in subadult and adult groups from France and Norway were similar $\left(\sim 15.7 \mathrm{mg} \mathrm{kg}^{-1}\right)$ although the ospreys came from 2000s and $1970 \mathrm{~s}$ (Table 4). It seems that in Europe $\mathrm{Hg}$ exposure of osprey has not decreased.

The share of hepatic and nephric $\mathrm{MeHg}$ in waterbirds varies within wide ranges and depends on environmental factors and the age/size/physiological condition of individuals, the species and trophic group (DesGranges et al. 1998; Scheuhammer et al. 2007). In contrast to the liver and kidneys, it is believed that in avian muscle, $\mathrm{MeHg}$ demethylation process occurs to a small extent, and therefore the $\mathrm{MeHg}$ share is very high (>80\%). This was confirmed among piscivorous ospreys, mergansers and loons (Norheim and Frøslie 1978; Scheuhammer et al. 1998; Hopkins et al. 2007; Kalisinska et al. 2014). In contrast to these species, the mentioned Norwegian groups I and II of the white-tailed eagle and the Polish one, despite some differences in $\mathrm{THg}$ concentrations in muscle $\left(1.3,3.7\right.$ and $1.1 \mathrm{mg} \mathrm{kg}^{-1}$, respectively), had muscle \% MeHg similar $(\sim 60 \%)$ and much lower than for previously studied piscivorous birds. Our and Norwegian investigations indicate the existence of a relatively intense demethylation of $\mathrm{MeHg}$ in the tissue of white-taile eagle, and document a greater interspecific variability that previously thought. In our study, values of $\% \mathrm{MeHg}$ were similar in the eagle's muscle and brain $(\sim 60 \%)$. Although the brain $\mathrm{THg}$ level was low $\left(0.6 \mathrm{mg} \mathrm{kg}^{-1}\right)$, the $\% \mathrm{MeHg}$ was the same as in the bald eagle from the U.S. Great Lakes, despite its higher $\mathrm{THg}$ level $\left(2.8 \mathrm{mg} \mathrm{kg}^{-1}\right.$ dw) (Rutkiewicz et al. 2011). In the bald eagle, it was demonstrated that demethylation of $\mathrm{MeHg}$ increased as $\mathrm{THg}$ in the brain increased, like in the liver (Scheuhammer et al. 2008; Rutkiewicz et al. 2011).

Scientists agree that $\mathrm{MeHg}$ easily crosses the brain-blood barrier and strongly affects a brain and the neuromuscular synapses of warm-blooded vertebrates (Clarkson and Magos 2006; Scheuhammer et al. 2007, 2008). Experimental studies on the impact of small amounts of $\mathrm{Hg}$ in the avian brain, carried out at biochemical and behavioural levels, have shown that $\mathrm{MeHg}$ concentrations in the range of even $0.2-1.0 \mathrm{mg} \mathrm{kg}^{-1} \mathrm{dw}$ in the fish can lead to disorders in individuals and have ecological consequences. Eating such a diet probably does not always result in moderate or large $\mathrm{Hg}$ concentrations in avian brains and other tissues. However, even low $\mathrm{Hg}$ concentrations in brain can cause alteration of pairing behaviour, slowing down the escape response (for example, from an oncoming train), too late recognition of 
dangers during flight, such as overhead power lines and wind power rotors at the growing number of wind farms in the EU (Krone et al. 2006; Frederick and Jayasena 2011).

\section{CONCLUSION}

This study helps to broaden knowledge on the degree of $\mathrm{Hg}$ intoxication in two rare bird species in Europe. In the past 25 years, there has been a decline in $\mathrm{THg}$ concentrations in soft tissues of white-tailed eagles among Baltic populations, especially Polish-German ones. It has been shown that among the piscivorous birds, there is considerable variation in the share of $\mathrm{MeHg}$ in $\mathrm{THg}$. Moreover, \% $\mathrm{MeHg}$ in the muscle of the white-tailed eagle is significantly lower $(\sim 60 \%)$ than in other piscivorous birds $(>80 \%)$. Unlike the white-tailed eagle, it seems that in the European osprey concentrations of $\mathrm{THg}$ in soft tissues have not decreased over the period, but comparative data for this species are extremely scarce.

Acknowledgments We thank ornithologists of the Eagle Protection Committee, foresters and employees of national and landscape parks for the collection of birds; M. Kalisinski and A. Jackowski for the bird age determinations, and D. Kalisinski for the preparation of Figures.

Open Access This article is distributed under the terms of the Creative Commons Attribution License which permits any use, distribution, and reproduction in any medium, provided the original author(s) and the source are credited.

\section{REFERENCES}

Anderwald, D., T. Janiszewski, T. Przybylinski, and P. Zielinski. 2007. Developing of breeding population of white-tailed eagle Haliaeetus albicilla in lodz voivodship in years 1985-2007. Studia i Materialy Centrum Edukacji Przyrodniczo-Lesnej 9: 419-430 [in Polish, English summary].

BirdLife International. 2004. Birds in Europe. Population estimates, trends and conservation status. Cambridge, UK: BirdLife Conservation Series 12, 147 pp.

Cenian, Z., J. Lontkowski, and T. Mizera. 2006. Population growth and re-expansion of the white-tailed eagle Haliaeetus albicilla following effective species protection in Poland. Studia $i$ Materialy Centrum Edukacji Przyrodniczo-Lesnej 6: 55-63 [in Polish, English summary].

Clarkson, T.W., and L. Magos. 2006. The toxicology of mercury and its chemical compounds. Critical Reviews in Toxicology 36: 609-662.

Debski, B., K. Olendrzynski, J. Cieslinska, I. Kargulewicz, J. Skoskiewicz, A. Olecka, and K. Kania. 2009. Air emission inventory of SO, NO, NH, ashes, heavy metals, NMVOC and POP in Poland in year 2007. KASHUE, Environmental Protection Institute, Warsaw, Poland [in Polish].

DesGranges, J.L., J. Rodrigue, B. Tardif, and M. Laperle. 1998. Mercury accumulation and biomagnification in ospreys (Pandion haliaetus) in the James Bay and Hudson Bay regions of Québec.
Archives of Environmental Contamination and Toxicology 35: 330-341.

Dittmann, J., M. Altmeyer, K. Dmowski, J. Krüger, P. Müller, and G. Wagner. 1990. Mercury concentrations in a white-tailed eagle (Haliaetus albicilla) from the vicinity of Warsaw, Poland. Environmental Conservation 17: 75-77.

Falandysz, J., and B. Jakuczun. 1986. Polychlorine compounds and trace elements in tissues and organs of white-tailed eagle (Haliaeetus albicilla). Bromatologia i Chemia Toksykologiczna 19: 131-133 [in Polish, English summary].

Falandysz, J., W. Król, and B. Jakuczun. 1987. Metals and polychloric compounds in tissues and eggs of white-tailed eagle Heliaeetus albicilla (L.) and in eggs of lesser spotted eagle Aquila pomarina (Brehm). Bromatologia $i$ Chemia Toksykologiczna 20: 233-239 [in Polish, English summary].

Falandysz, J., B. Jakuczun, and T. Mizera. 1988. Metals and organochlorines in four female white-tailed eagles. Marine Pollution Bulletin 19: 521-526.

Falandysz, J., H. Ichihashi, K. Szymczyk, S. Yamasaki, and T. Mizera. 2001. Metallic elements and metal poisoning among white-tailed sea eagles from the Baltic South Coast. Marine Pollution Bulletin 42: 1190-1193.

Forsman, D. 1999. The raptors of Europe and the Middle East. A handbook of field identification, 589. London: T \& AD Poyser.

Frederick, P., and N. Jayasena. 2011. Altered pairing behaviour and reproductive success in white ibises exposed to environmentally relevant concentrations of methylmercury. Proceedings of the Royal Society B 278: 1851-1857.

Gochfeld, M. 2003. Cases of mercury exposure, bioavailability, and absorption. Ecotoxicology and Environmental Safety 56: 174-179.

Gorecki, J., S. Díez, M. Macherzynski, E. Kalisinska, and J. Golas. 2013. Improvements and application of a modified gas chromatography atomic fluorescence spectroscopy method for routine determination of methylmercury in biota samples. Talanta 115: 675-680.

Häkkinen, I., and E. Häsänen. 1980. Mercury in eggs and nestlings of the osprey (Pandion haliaetus) in Finland and its bioaccumulation from fish. Annales Zoologici Fennici 17: 131-139.

Hauff, P., and T. Mizera. 2006. Distribution and density of whitetailed sea eagles Haliaeetus albicilla in Germany and Poland: A current atlas-map. Vogelwarte 44: 134-136 [in German, English summary].

Henriksson, K., E. Karppanen, and M. Helminen. 1966. High residue of mercury in Finnish white-tailed eagles. Ornis Fennica 43: $38-45$.

Holt, G., A. Frøslie, and G. Norheim. 1979. Mercury, DDE, and PCB in the avian fauna in Norway 1965-1976. Acta Veterinaria Scandinavica 70: 1-28.

Hopkins, W.A., L.B. Hopkins, J.M. Unrine, J. Snodgrass, and J.D. Elliot. 2007. Mercury concentrations in tissues of osprey from the Carolinas, USA. Journal of Wildlife Management 71: 1819-1829.

Jensen, S., A.G. Johnels, M. Olsson, and T. Westermark. 1972. The avifauna of Sweden as indicators of environmental contamination with mercury and chlorinated hydrocarbons. In Proceedings of the 15th International Ornithlogical Congress, ed. E.J. Brill, 455-465 pp. Hague, Netherlands.

Johnels, A., and T. Westermark. 1969. Mercury contamination of the environment in Sweden. In: Chemical fallout, ed. M.W. Miller, and G.G., Berg, 221-239 pp. Springfield, IL: Chrales C. Thomas.

Kalisinska, E., W. Salicki, and A. Jackowski. 2006. Six trace metals in white-tailed eagle from north-western Poland. Polish Journal of Environmental Studies 15: 727-735.

Kalisinska, E., J. Gorecki, A. Okonska, B. Pilarczyk, A. TomzaMarciniak, H. Budis, N. Lanocha, D.I. Kosik-Bogacka, et al. 
2014. Mercury and selenium in the muscle of piscivorous common mergansers (Mergus merganser) from a seleniumdeficient European country. Ecotoxicology and Environmental Safety 101: 107-115.

Kenntner, N., F. Tataruch, and O. Krone. 2001. Heavy metals in soft tissue of white-tailed eagles found dead or moribund in Germany and Austria from 1993 to 2000. Environmental Toxicology and Chemistry 20: 1831-1837.

Kitowski, I., R. Kowalski, A. Komosa, J. Lechowski, G. Grzywaczewski, R. Scibor, G. Pitucha, and M. Chrapowicki. 2012. Diversity of total mercury concentrations in kidneys of birds from Eastern Poland. Ecology (Bratislava) 31: 12-21.

Koeman, J.H., R.H. Hadderingh, and M.F.I.J. Bijleveld. 1972. Persistent pollutants in the white-tailed eagle (Haliaeetus albicilla) in the Federal Republic of Germany. Biological Conservation 4: 373-377.

Komosa, A., I. Kitowski, R. Kowalski, G. Pitucha, Z. Komosa, and J. Grochowic. 2009. Total mercury concentration in kidneys of birds of prey from different part of Poland-some interspecies and geographical differences. Ecological Chemistry and Engineering 16: 19-28.

Krone, O., F. Wille, N. Kenntner, D. Boertmann, and F. Tataruch. 2004. Mortality factors, environmental contaminants, and parasites of white-tailed sea eagles from Greenland. Avian Diseases 48: 417-424.

Krone, O., T. Stjernberg, N. Kenntner, F. Tataruch, J. Koivusaari, and I. Nuuja. 2006. Mortality Factors, Helminth Burden, and Contaminant Residues in White-Tailed Sea Eagles (Haliaeetus albicilla) From Finland. AMBIO 35: 98-104.

Larson, H. 2014. The minamata convention on mercury: Risk in perspective. Lancet 383: 198-199.

Lemarchand, C., R. Rosoux, M.E. Pénide, and B. Berny. 2012. Tissue concentrations of pesticides, PCBs and metals among ospreys, Pandion haliaetus, collected in France. Bulletin of Environmental Contamination and Toxicology 88: 89-93.

Mizera, T. 2009. The osprey, Pandion haliaetus, situation in Poland at the start of the 21st century. Studia $i$ Materialy Centrum Edukacji Przyrodniczo-Lesnej 11: 45-55 [in Polish, English summary].

Norheim, G., and A. Frøslie. 1978. The degree of methylation and organ distribution of mercury in some birds of prey in Norway. Acta Pharmacologica et Toxicologica 43: 196-204.

Oehme, G. 1981. Mercury residues in carcasses of white-tailed eagles Haliaeetus albicilla (L.) between 1967 and 1978. Hycernia NF 18: 353-364 [in German, English summary].

Polak-Juszczak, L. 2013. Trace elements in the livers of cod (Gadus morhua L.) from the Baltic Sea: Levels and temporal trends. Environmental Monitoring and Assessment 185: 687-694.

Panasiuk D., and A. Glodek. 2013. Substance flow analysis for mercury emission in Poland. E3S Web of Conferences 1, 38001.

Rutkiewicz, J., D.H. Nam, T. Cooley, K. Neumann, I.B. Padilla, W. Route, S. Strom, and N. Basu. 2011. Mercury exposure and neurochemical impacts in bald eagles across several Great Lakes states. Ecotoxicology 20: 1669-1676.

Shore, R.F., M.G. Pereira, L.A. Walker, and D.R. Thompson. 2011. Mercury in nonmarine birds and mammals. In Environmental contaminants in biota, ed. W.N. Beyer, and J.P. Meador, 609-642. Boca Raton: CRC Press.

Scheuhammer, A.M., A.H. Wong, and D. Bond. 1998. Mercury and selenium accumulation in common loons (Gavia immer) and common mergansers (Mergus merganser) from eastern Canada. Environmental Toxicology and Chemistry 17: 197-201.

Scheuhammer, A.M., M.W. Meyer, M.B. Sandheinrich, and M.W. Murray. 2007. Effects of Environmental Methylmercury on Health of Wild Birds, Mammals, and Fish. AMBIO 36: 12-18.
Scheuhammer, A.M., N. Basu, N.M. Burgess, J.E. Elliott, G.D. Campbell, M. Wayland, L. Champoux, and J. Rodrigue. 2008. Relationships among mercury, selenium, and neurochemical parameters in common loons (Gavia immer) and bald eagles (Haliaeetus leucocephalus). Ecotoxicology 17: 93-101.

Weech, S.A., L.K. Wilson, K.M. Langelier, and J.E. Elliott. 2003. Mercury residues in livers of bald eagles (Haliaeetus leucocephalus) found dead or dying in British Columbia, Canada (1987-1994). Archives of Environmental Contamination and Toxicology 45: 562-569.

\section{AUTHOR BIOGRAPHIES}

Elzbieta Kalisinska $(\square)$ is a Full Professor of Biology, Head of the Department of Biology and Medical Parasitology, Pomeranian Medical University, Poland

Address: Department of Biology and Medical Parasitology, Pomeranian Medical University, Powstancow Wielkopolskich Av. 72, 70-111 Szczecin, Poland.

e-mail: ekalist@pum.edu.pl

Jerzy Gorecki is an Assistant Professor at the Department of Coal Chemistry and Environmental Sciences, Faculty of Energy and Fuels, AGH University of Science and Technology, Poland

Address: Department of Coal Chemistry and Environmental Sciences, Faculty of Energy and Fuels, AGH University of Science and Technology, Mickiewicza Av. 30, 30-059 Kraków, Poland. e-mail: gorecki@agh.edu.pl

Natalia Lanocha is an Assistant at the Department of Biology and Medical Parasitology, Pomeranian Medical University, Poland Address: Department of Biology and Medical Parasitology, Pomeranian Medical University, Powstancow Wielkopolskich Av. 72, 70-111 Szczecin, Poland.

e-mail: nlanocha@o2.pl

Anna Okonska is a Doctoral Candidate at the Department of Coal Chemistry and Environmental Sciences, Faculty of Energy and Fuels, AGH University of Science and Technology, Poland

Address: Department of Coal Chemistry and Environmental Sciences, Faculty of Energy and Fuels, AGH University of Science and Technology, Mickiewicza Av. 30, 30-059 Kraków, Poland. e-mail: aokonska@agh.edu.pl

Javier B. Melgarejo is an Erasmus Exchange Student of Chemistry Faculty (from Universidad de Sevilla, Spain) at the Department of Coal Chemistry and Environmental Sciences, Faculty of Energy and Fuels, AGH University of Science and Technology, Poland

Address: Department of Coal Chemistry and Environmental Sciences, Faculty of Energy and Fuels, AGH University of Science and Technology, Mickiewicza Av. 30, 30-059 Kraków, Poland. e-mail: javi_borrero@hotmail.com

Halina Budis an Assistant Professor at the Department of Health Education, University of Szczecin, Poland

Address: Department of Health Education, University of Szczecin, al. Piastow 40b bl. 6, 71-065 Szczecin, Poland.

e-mail: halina.budis@wp.pl

Izabella Rzad is an Assistant Professor at the Department of Ecology and Environment Protection, University of Szczecin, Poland Address: Department of Ecology and Environment Protection, University of Szczecin, Waska 13, 75-415 Szczecin, Poland. e-mail: izabela.rzad@univ.szczecin.pl 
Jerzy Golas is a Full Professor of Chemistry and Head of the Department of Coal Chemistry and Environmental Sciences, Faculty of Energy and Fuels, AGH University of Science and Technology, Poland
Address: Department of Coal Chemistry and Environmental Sciences, Faculty of Energy and Fuels, AGH University of Science and Technology, Mickiewicza Av. 30, 30-059 Kraków, Poland. e-mail: jgolas@agh.edu.pl 